\title{
Inhibition of BCL11B induces downregulation of PTK7 and results in growth retardation and apoptosis in T-cell acute lymphoblastic leukemia
}

Kehan $\mathrm{Li}^{1 \dagger}$, Cunte Chen ${ }^{1 \dagger}$, Rili Gao ${ }^{1 \dagger}$, Xibao Yu', Youxue Huang ${ }^{1}$, Zheng Chen', Zhuandi Liu', Shaohua Chen', Gengxin Luo ${ }^{2}$ Xin Huang ${ }^{3}$, Grzegorz K. Przybylski ${ }^{4^{*}}$, Yangqiu Li ${ }^{1^{*}}$ and Chengwu Zeng ${ }^{1 *}$ (i)

\begin{abstract}
T-cell acute lymphoblastic leukemia (T-ALL) is an aggressive subtype of leukemia with poor prognosis, and biomarkers and novel therapeutic targets are urgently needed for this disease. Our previous studies have found that inhibition of the B-cell leukemia/lymphoma 11B (BCL11B) gene could significantly promote the apoptosis and growth retardation of T-ALL cells, but the molecular mechanism underlying this effect remains unclear. This study intends to investigate genes downstream of $B C L 11 B$ and further explore its function in T-ALL cells. We found that PTK7 was a potential downstream target of BCL11B in T-ALL. Compared with the healthy individuals (HIs), PTK7 was overexpressed in T-ALL cells, and BCL11B expression was positively correlated with PTK7 expression. Importantly, $B C L 11 B$ knockdown reduced PTK7 expression in T-ALL cells. Similar to the effects of BCL11B silencing, downregulation of PTK7 inhibited cell proliferation and induced apoptosis in Molt-4 cells via up-regulating the expression of tumor necrosis factor (TNF)-related apoptosis-inducing ligand (TRAIL) and p27. Altogether, our studies suggest that PTK7 is a potential downstream target of $B C L 11 B$, and downregulation of PTK7 expression via inhibition of the $B C L 11 B$ pathway induces growth retardation and apoptosis in T-ALL cells.
\end{abstract}

\section{To the Editor:}

The B-cell leukemia/lymphoma 11B (BCL11B) gene plays an important role in the development of T-cell acute lymphoblastic leukemia (T-ALL) $[1,2]$. Our previous studies have shown that down-regulation of $B C L 11 B$ effectively inhibits proliferation and induces apoptosis of T-ALL cells [3, 4]. PTK7 (protein tyrosine kinase 7), the target protein of sgc8 DNA aptamer, has been identified

\footnotetext{
* Correspondence: grzegorz.przybylski@igcz.poznan.pl;

yangqiuli@hotmail.com; bio-zcw@163.com

${ }^{\dagger}$ Kehan Li, Cunte Chen and Rili Gao contributed equally to this work.

${ }^{4}$ Institute of Human Genetics, Polish Academy of Sciences, Strzeszyńska 32, 60-479 Poznań, Poland

${ }^{1}$ Key Laboratory for Regenerative Medicine of Ministry of Education, Institute of Hematology, Jinan University, Guangzhou 510632, P.R. China

Full list of author information is available at the end of the article
}

as a potential biomarker for T-ALL [5]. However, the detailed role and downstream molecular mechanisms of $B C L 11 B$ and relationship between BCL11B and PTK7 remain undefined. In this study, we determined the $B C L 11 B$ target genes in T-ALL patients using the Gene Expression Omnibus (GEO) database and used specific siRNAs (small interfering ribonucleic acid) to downregulate the expression of this gene in T-ALL cell lines to explore the mechanism.

A total of 220 de novo T-ALL patients from the GEO database and 36 peripheral blood mononuclear cells (PBMCs) of T-ALL from our center were used for analysis and validation. In GSE13159 and GSE28497 datasets, we found that the $B C L 11 B$ was highly expressed in T-ALL $(P<0.001$, Fig. 1a and S1a). These

C C The Author(s). 2021 Open Access This article is licensed under a Creative Commons Attribution 4.0 International License, which permits use, sharing, adaptation, distribution and reproduction in any medium or format, as long as you give appropriate credit to the original author(s) and the source, provide a link to the Creative Commons licence, and indicate if changes were made. The images or other third party material in this article are included in the article's Creative Commons licence, unless indicated otherwise in a credit line to the material. If material is not included in the article's Creative Commons licence and your intended use is not permitted by statutory regulation or exceeds the permitted use, you will need to obtain permission directly from the copyright holder. To view a copy of this licence, visit http://creativecommons.org/licenses/by/4.0/. The Creative Commons Public Domain Dedication waiver (http://creativecommons.org/publicdomain/zero/1.0/) applies to the data made available in this article, unless otherwise stated in a credit line to the data. 


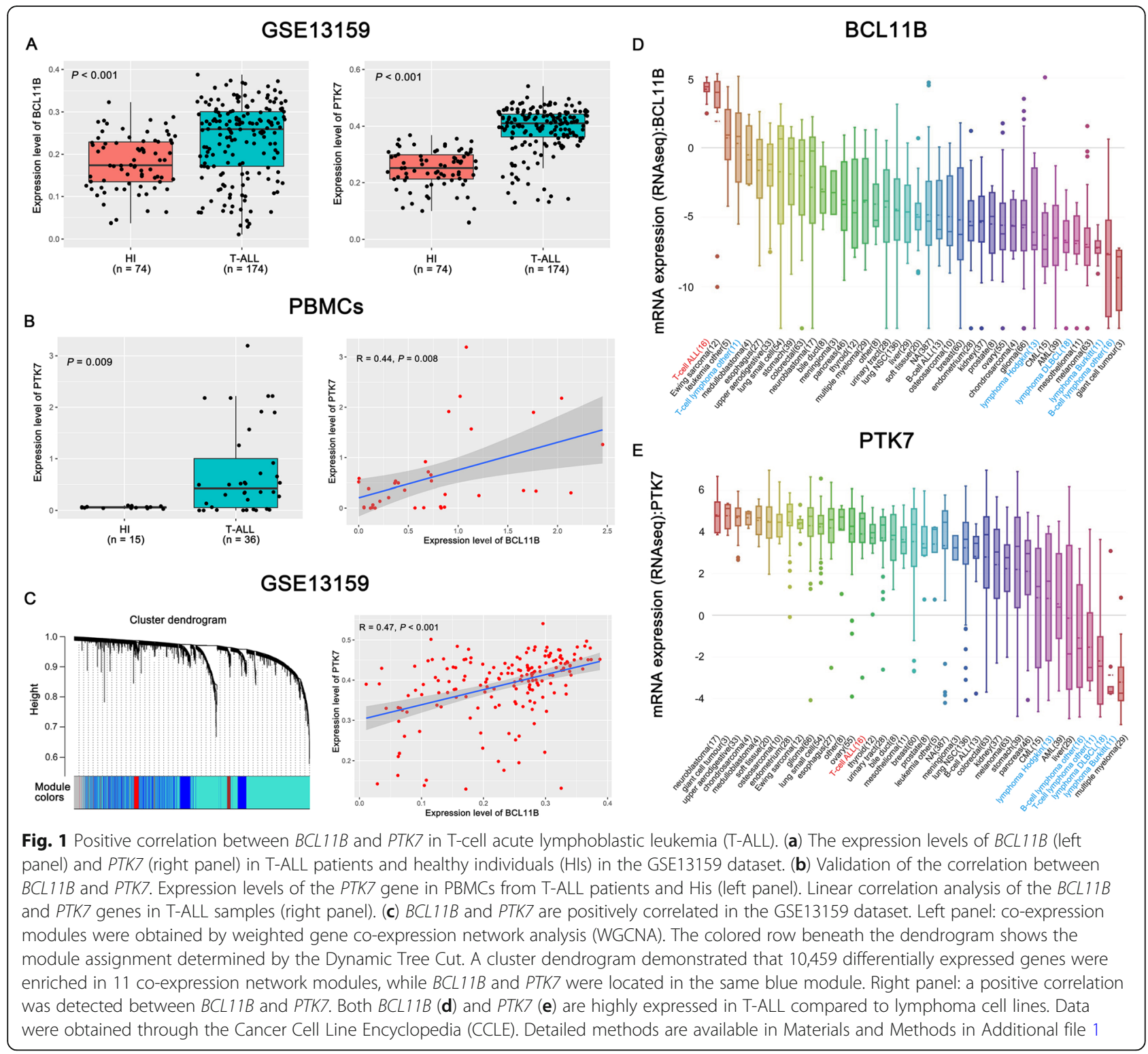

results were consistent with our previous study [6]. Moreover, similar results of PTK7 were found in GSE13159, GSE28497 and PBMCs $(P<0.05$, Fig. 1a-b and $\mathrm{S} 1 \mathrm{~b}$ ), which was also in line with previous report [7]. Next, to identify genes downstream of $B C L 11 B$, the $B C L 11 B$ co-expression network was further characterized by weighted gene co-expression network analysis (WGCNA). Interestingly, Bioinformatics analysis [8] showed a significant positive correlation between the expression of BCL11B and PTK7 in GSE13159, GSE28497 and PBMCs $(P<0.05$, Fig. 1b-c and S1c). Furthermore, we studied the expression of $B C L 11 B$ and PTK7 in different cell lines from the Cancer Cell Line Encyclopedia (CCLE). Previous studies have shown that BCL11B is overexpressed in the acute type of adult T-cell leukemia/ lymphoma (ATLL), and it is under-expressed in other lymphoma type. Consistently, BCL11B and PTK7 was highly expressed in the T-ALL cells line but had low expression in the lymphoma cell lines (Fig. 1d-e). Based on these findings, we proposed that PTK7 might be an important gene downstream of BCL11B in T-ALL.

We sought to further verify the association between $B C L 11 B$ and PTK7 in both T-ALL and non-T-ALL cell lines at the mRNA and protein levels. As shown in Fig. 2a, BCL11B and PTK7 mRNA were highly expressed in T-ALL cell lines (Jurkat and Molt-4), but almost absent in BCL11B-negative Burkitt lymphoma cell line (Raji). Next, an aptamer was used to determine the cell surface protein expression of PTK7 in Jurkat and Raji cells. Sgc-8, the PTK7-specific aptamer, was labeled with a Cy5 fluorescent reporter and incubated with Jurkat and Raji cells under different concentrations, which revealed 


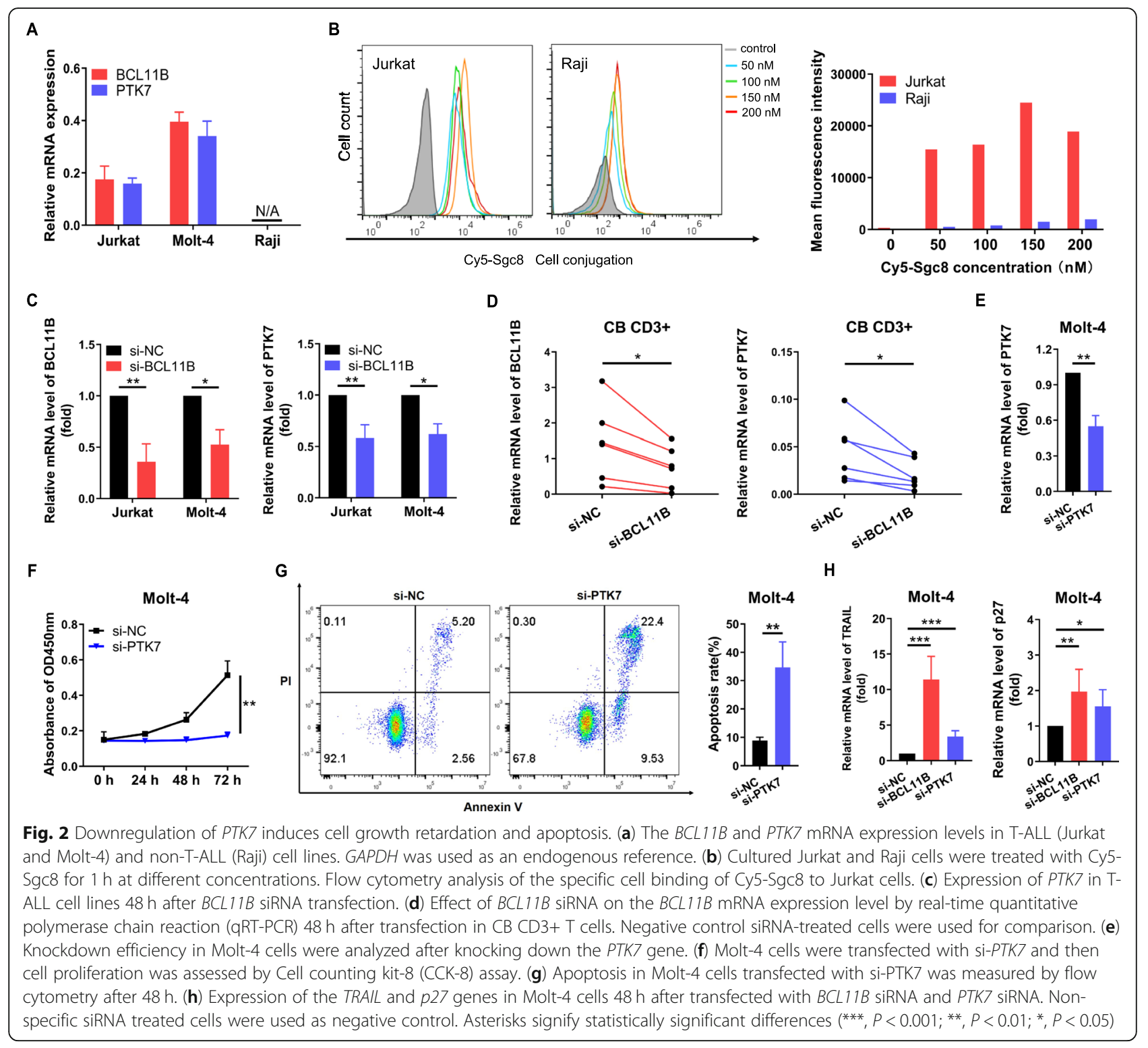

that $\mathrm{Cy} 5-\mathrm{Sgc} 8$ specifically bound to Jurkat cells but did not react with Raji cells (Fig. 2b). Excitingly, there was a significant decrease in PTK7 mRNA expression after silencing $B C L 11 B$ expression in the Jurkat and Molt-4 cells and cord blood (CB) CD3+ T cells (Fig. 2c-d). These results confirmed that $P T K 7$ might be regulated by the $B C L 11 B$ signaling pathway in both T-ALL cell lines and human $\mathrm{CD} 3+\mathrm{T}$ cells. Based on the above results, we attempted to further understand the role of PTK7 in TALL cells. Compared to the negative control, the proliferation of Molt-4 cells transfected with PTK7-siRNA was significantly decreased $(P<0.01$, Fig. 2e-f). Meanwhile, the Annexin V/PI-positive cells demonstrated a significant increase for PTK7-siRNA transfected Molt-4 cells, reaching $34.66 \pm 5.21 \%(P=0.008$, Fig. $2 g)$. In addition, recent reports have shown that tumor necrosis factor (TNF)-related apoptosis-inducing ligand (TRAIL) and $p 27$ are found to be involved in the $B C L 11 B$ pathway to regulate the cell cycle and apoptosis $[3,9,10]$. Interestingly, significant increases in the expression levels of TRAIL and p27 were detected in the PTK7-siRNA group, which was consistent with the trend exhibited in the BCL11B-siRNA group (Fig. 2h). These data suggested that PTK7 was a downstream BCL11B target gene in T-ALL cell growth and apoptosis.

In summary, this is the first report demonstrating that PTK7 is an important functional downstream target gene of $B C L 11 B$ in T-ALL. Our study provides rationale for targeting $B C L 11 B / P T K 7$ in the development of therapeutics for $\mathrm{T}$-cell malignancies. 


\section{Abbreviations}

BCL11B: B-cell leukemia/lymphoma 11B; CCLE: Cancer cell line encyclopedia; GEO: Gene expression omnibus database; HI: Healthy individual; PTK7: Protein tyrosine kinase receptor 7; PBMCs: Peripheral blood mononuclear cells; siRNA: Small interfering ribonucleic acid; T-ALL: T-cell acute lymphoblastic leukemia; TRAIL: Tumor necrosis factor (TNF)-related apoptosis-inducing ligand; WGCNA: Weighted gene co-expression network analysis

\section{Supplementary Information}

The online version contains supplementary material available at https://doi. org/10.1186/s40364-021-00270-3

Additional file 1. Materials and Methods.

Additional file 2: Figure S1. Expression patterns of $B C L 11 B$ and PTK7 in the GSE28497 dataset. High expression of BCL11B (A) and PTK7 (B) in TALL. (C) BCL11B and PTK7 had a positive correlation.

\section{Acknowledgements}

Not applicable.

\section{Authors' contributions}

Kehan Li, Cunte Chen and Rili Gao performed the experiments, wrote the paper, and analyzed the data. Xibao Yu, Youxue Huang, Zheng Chen, Zhuandi Liu, Shaohua Chen and Xin Huang helped analyze the data. Gengxin Luo provided primary cells and patient information. Grzegorz K. Przybylski, Yangqiu Li, and Chengwu Zeng designed the study and wrote the manuscript. All authors read and approved the final manuscript.

\section{Funding}

This work was supported by grants from Intergovernmental International Cooperation on Scientific and Technological Innovation project of Chinese Ministry of Science and Technology (No. 2017YFE0131600), the Guangdong Science and Technology Project (No. 2020A0505100042), the National Science Center, Poland (No. DEC-2013/09/B/NZ1/01867) (GKP.), the Polish National Centre for Research and Development (No. WPC1/BCL/2019) (GKP), the National Natural Science Foundation of China (No.81770158), and the Pearl River S\&T Nova Program of Guangzhou, China (No. 201906010002).

\section{Availability of data and materials}

Data available on request.

\section{Declarations}

Ethics approval and consent to participate

This study was approved by the ethics committee of the affiliated hospitals of Jinan University. Written informed consent was obtained from all patients.

\section{Consent for publication}

Not applicable.

\section{Competing interests}

The authors declare that they have no competing interests.

\section{Author details}

${ }^{1}$ Key Laboratory for Regenerative Medicine of Ministry of Education, Institute of Hematology, Jinan University, Guangzhou 510632, P.R. China. ${ }^{2}$ Department of Hematology, First Affiliated Hospital, Jinan University, Guangzhou 510632, P.R. China. ${ }^{3}$ Department of Hematology, Guangdong General Hospital (Guangdong Academy of Medical Sciences), Guangzhou 510080, P.R. China. ${ }^{4}$ Institute of Human Genetics, Polish Academy of Sciences, Strzeszyńska 32, 60-479 Poznań, Poland.
Received: 5 January 2021 Accepted: 19 February 2021

Published online: 04 March 2021

\section{References}

1. Ha VL, Luong A, Li F, Casero D, Malvar J, Kim YM, et al. The T-ALL related gene $B C L 11 B$ regulates the initial stages of human $T$-cell differentiation. Leukemia. 2017;31(11):2503-14.

2. Li L, Leid M, Rothenberg EV. An early T cell lineage commitment checkpoint dependent on the transcription factor Bcl11b. Science. 2010; 329(5987):89-93.

3. Grabarczyk P, Przybylski GK, Depke M, Völker U, Bahr J, Assmus K, et al. Inhibition of BCL11B expression leads to apoptosis of malignant but not normal mature T cells. Oncogene. 2007;26(26):3797-810.

4. Huang X, Chen S, Shen Q, Chen S, Yang L, Grabarczyk P, et al. Down regulation of $B C L 11 B$ expression inhibits proliferation and induces apoptosis in malignant T cells by BCL11B-935-siRNA. Hematology. 2011;16(4):236-42.

5. Zhang Y, Li M, Gao X, Chen Y, Liu T. Nanotechnology in cancer diagnosis: progress, challenges and opportunities. J Hematol Oncol. 2019;12(1):137.

6. Huang $X$, Chen S, Shen $Q$, Yang L, Li B, Zhong L, et al. Analysis of the expression pattern of the $B C L 11 B$ gene and its relatives in patients with $T$ cell acute lymphoblastic leukemia. J Hematol Oncol. 2010;3(1):44.

7. Jiang $G$, Zhang M, Yue B, Yang M, Carter C, Al-Quran SZ, et al. PTK7: a new biomarker for immunophenotypic characterization of maturing $T$ cells and $T$ cell acute lymphoblastic leukemia. Leuk Res. 2012;36(11):1347-53.

8. Chen C, Liang C, Wang S, Chio C, Zhang Y, Zeng C, et al. Expression patterns of immune checkpoints in acute myeloid leukemia. J Hematol Oncol. 2020;13(1):28.

9. Kamimura K, Mishima Y, Obata M, Endo T, Aoyagi Y, Kominami R. Lack of Bcl11b tumor suppressor results in vulnerability to DNA replication stress and damages. Oncogene. 2007;26(40):5840-50.

10. Nie Y, Lu W, Chen D, Tu H, Guo Z, Zhou X, et al. Mechanisms underlying CD19-positive ALL relapse after anti-CD19 CAR T cell therapy and associated strategies. Biomark Res. 2020;8:18.

\section{Publisher's Note}

Springer Nature remains neutral with regard to jurisdictional claims in published maps and institutional affiliations.

\section{Ready to submit your research? Choose BMC and benefit from:}

- fast, convenient online submission

- thorough peer review by experienced researchers in your field

- rapid publication on acceptance

- support for research data, including large and complex data types

- gold Open Access which fosters wider collaboration and increased citations

- maximum visibility for your research: over $100 \mathrm{M}$ website views per year

At BMC, research is always in progress.

Learn more biomedcentral.com/submissions 